\title{
Generation of myeloid-derived suppressor cells using prostaglandin $\mathrm{E}_{2}$
}

Nataša Obermajer ${ }^{1}$ and Pawel Kalinski $i^{1,2,3,4,5^{*}}$

\begin{abstract}
Myeloid-derived suppressor cells (MDSCs) are natural immunosuppressive cells and endogenous inhibitors of the immune system. We describe a simple and clinically compatible method of generating large numbers of MDSCs using the cultures of peripheral blood-isolated monocytes supplemented with prostaglandin $E_{2}\left(P_{G} E_{2}\right)$. We observed that $\mathrm{PGE}_{2}$ induces endogenous cyclooxygenase (COX)2 expression in cultured monocytes, blocking their differentiation into $\mathrm{CD}_{1} \mathrm{a}^{+}$dendritic cells (DCs) and inducing the expression of indoleamine 2,3-dioxygenase 1, IL-4Ra, nitric oxide synthase 2 and IL-10 - typical MDSC-associated suppressive factors. The establishment of a positive feedback loop between $\mathrm{PGE}_{2}$ and $\mathrm{COX}$, the key regulator of $\mathrm{PGE}_{2}$ synthesis, is both necessary and sufficient to promote the development of $\mathrm{CD} 1 \mathrm{a}^{+} \mathrm{DCs}$ to $\mathrm{CD} 14^{+} \mathrm{CD} 33^{+} \mathrm{CD} 34^{+}$monocytic MDSCs in granulocyte macrophage colony stimulating factor/LL-4-supplemented monocyte cultures, their stability, production of multiple immunosuppressive mediators and cytotoxic $T$ lymphocyte-suppressive function. In addition to $\mathrm{PGE}_{2}$, selective E-prostanoid receptor (EP)2- and EP4-agonists, but not EP3/1 agonists, also induce the MDSCs development, suggesting that other activators of the EP2/4- and EP2/4-driven signaling pathway (adenylate cyclase/cAMP/PKA/ CREB) may be used to promote the development of suppressive cells. Our observations provide a simple method for generating large numbers of MDSCs for the immunotherapy of autoimmune diseases, chronic inflammatory disorders and transplant rejection.
\end{abstract}

Keywords: Cancer, COX2, Dendritic cells, Human, Immune dysfunction, Immunotherapy, Myeloid-derived suppressor cells, PGE, Transplantation

\section{Biology of myeloid-derived suppressor cells}

Dendritic cells (DCs) are key initiators and regulators of immune responses [1-3]. Therapeutic programming of DCs to suppress their function has been shown beneficial in autoimmunity and transplantation [4-6]. In contrast to DCs, suppressive macrophages [7] and myeloid-derived suppressor cells (MDSCs), originally shown to accumulate at the site of tumors, suppress the ability of $\mathrm{CD}^{+} \mathrm{T}$ cells to mediate effective responses against cancer cells, but can be beneficial in controlling autoimmune phenomena or transplant rejection [8-10].

MDSCs [10], important mediators of tumor-induced immune dysfunction and cancer progression [11], represent a heterogeneous population of immature myeloid

\footnotetext{
*Correspondence: kalinskip@upmc.edu

'Departments of Surgery, University of Pittsburgh, Hillman Cancer Center, Pittsburgh, PA 15213, USA

${ }^{2}$ Departments of Immunology, University of Pittsburgh, Hillman Cancer Center, Pittsburgh, PA 15213, USA

Full list of author information is available at the end of the article
}

cells (iMCs) involving precursors of macrophages, granulocytes, and DCs. MDSCs express CD34, common myeloid marker CD33, macrophage/DCs marker CD11b, and IL4R $\alpha$ (CD124), but lack expression of the lineage (Lin) markers of DCs and other mature myeloid cells $[10,12]$. Human MDSCs are defined as $\mathrm{CD} 33^{+} \mathrm{Lin}^{-} \mathrm{HLA}^{-\mathrm{DR}^{-/ \text {low }}}$ cells. Recent studies demonstrate that monocytic MDSCs from patients with melanoma [13], prostate cancer [14], gastrointestinal malignancies [15], hepatocellular carcinoma $[16,17]$ and glioblastoma [18] show a CD14 ${ }^{+} \mathrm{CD} 11 \mathrm{~b}^{+} \mathrm{HLA}$ $\mathrm{DR}^{\text {low }}$ phenotype while neutrophil-related immature (i) MDSCs present in peripheral blood show CD15 expression [10].

MDSCs express high levels of immunosuppressive factors, such as indoleamine 2,3-dioxygenase (IDO) [19,20], IL-10 [12], arginase [21,22], inducible nitric oxide synthase (iNOS, NOS2) [22], nitric oxide, and reactive oxygen species [23] and use these molecules to suppress T-cell responses $[24,25]$. Their induction of natural killer cell

\section{Biomed Central}


anergy and reduced cytotoxicity is arginase-independent [16] but depends on transforming growth factor $\beta_{1}$ [26]. PD-L1/B7-H1, induced on MDSCs [27,28], suppresses antigen-specific immunity via interaction with regulatory $\mathrm{T}$ cells $\left(\mathrm{T}_{\mathrm{reg}}\right)$ [27], enhanced $\mathrm{T}$ cell $\mathrm{IL}-10$ expression and reduced IFN- $\gamma$ production [28].

The presence of prostaglandin $\mathrm{E}_{2}\left(\mathrm{PGE}_{2}\right)$ at early stages of DC development was shown to suppresses the differentiation of human monocytes into functional $\mathrm{T}$ helper (Th)1-inducing CD1a ${ }^{+}$DCs [29]. Additionally, $\mathrm{PGE}_{2}$ is needed for the development of tumor-associated suppressive macrophages [30-32]. Our two recent reports [33,34] demonstrate that $\mathrm{PGE}_{2}$ is both required and sufficient to redirect the differentiation of human dendritic cells into monocytic MDSCs. It also mediates the induction of MDSC-associated suppressive factors in human MDSCs [21] in a mechanism involving the establishment of a positive feedback loop between $\mathrm{PGE}_{2}$ and cyclooxygenase (COX)-2 [33], the key regulator of $\mathrm{PGE}_{2}$ production [35]. Additionally, $\mathrm{PGE}_{2}$ has been shown to enhance the numbers of MDSCs in mouse models and induce their expansion ex vivo [36-38].

\section{In vitro generation of myeloid-derived suppressor cells}

Recent work in mice demonstrated that functional MDSCs can be generated in vitro from mouse embryonic stem cells and bone marrow hematopoietic stem cells, resulting in two subpopulations - CD $115^{+}$Ly- $6 \mathrm{C}^{+}$(equivalent to the monocytic $\mathrm{Gr}-1^{+} \mathrm{CD} 115^{+} \mathrm{F} 4 / 80^{+}$MDSCs found in tumorbearing mice) and $\mathrm{CD} 115^{+} \mathrm{Ly}-6 \mathrm{C}^{-}$cells (resembling the granulocyte/macrophage progenitors) [37,39-41]. Adoptive transfer of these MDSCs prevented graft-versus-host disease mediated by alloreactive $\mathrm{T}$ cells. While granulocytic MDSCs may induce non-specific immune suppression and suppress the effector phase of the allogeneic immune response at an early stage, the monocytic MDSCs emerge as the key subset needed to promote $\mathrm{T}_{\text {reg }}$ development and to establish long-term antigen-specific tolerance [37,39-41]. Another source of MDSCs is the bone marrow, which harbors a large reservoir of MDSCs. Recent studies have demonstrated an efficient growth factor/cytokine (granulocyte macrophage colony stimulating factor (GM-CSF) + GCSF or GM-CSF + IL-6 or IL-13)-induced expansion of MDSCs populations in vitro, utilizing bone marrow cells from either mice or human sources [42,43] to generate IL4R $\alpha^{+}$MDSCs. In mice these cells were able to impair the priming of $\mathrm{CD}^{+} \mathrm{T}$ cells, and enabled long-term acceptance of pancreatic islet allografts [43]. Furthermore, bone marrow progenitor cells can be induced by lipopolysaccharide to develop into $\mathrm{CD} 11 \mathrm{~b}^{+} \mathrm{Gr} 1^{\text {int }} \mathrm{F} 4 / 80^{+}$cells that, when adoptively transferred, suppressed allergen-induced airway inflammation in recipient mice [44]. Due to the massive accumulation of MDSCs in the spleens of tumor- bearing mice, the spleen is considered to be a reservoir of MDSCs and their precursors [45]. The drawback of these reported initiatives to develop MDSC-based therapeutic strategies is the lack of a reliable source of MDSCs.

For human treatment regimens the control of MDSCs in vitro by manipulating recipient myelomonocytic precursor cells appears most applicable. While there are low frequency and total numbers of MDSCs in peripheral blood (approximately 5\% of cells in healthy subjects), peripheral blood constitutes a very convenient source of myelomonocytic precursor cells for MDSC generation. Apart from the recently described cytokine regimens that showed the feasibility of in vitro expansion of bloodisolated MDSCs populations [46] the induction of human MDSCs has been proven a feasible in vitro approach for the generation of $\mathrm{CD} 14^{+} \mathrm{HLADR}^{\text {neg/low }}$ MDSCs by differentiation of isolated $\mathrm{CD} 14^{+}$cells in the presence of IL-4 + GM-CSF and tumor-derived microvesicles [46]. Alternatively, functional MDSCs can be induced in peripheral blood mononuclear cell (PBMC) cultures supplemented with several cytokine induction combinations, produced by tumor cell lines [47].

Our current data provides evidence for the feasibility of generating large numbers of monocytic MDSCs for the immunotherapy of autoimmune and inflammatory diseases, or transplant rejection by using a single common determining factor - $\mathrm{PGE}_{2}$, a common inflammation-associated master regulator of immune responses - that can redirect the development of $\mathrm{CD} 1 \mathrm{a}^{+} \mathrm{DCs}$ to $\mathrm{CD} 14^{+} \mathrm{CD} 33^{+} \mathrm{CD} 34^{+}$ monocytic MDSCs [48].

\section{Efficient generation of human myeloid-derived suppressor cells using prostaglandin $\mathrm{E}_{\mathbf{2}}$}

The development of functional MDSCs requires the inhibition of development of immunostimulatory antigen presenting cells and concomitant induction of suppressive functions [8]. The expansion of iMCs can be induced by factors such as GM-CSF, IL-6, or vascular endothelial growth factor [24,49-51]. The upregulation of MDSCassociated immunosuppressive factors and establishment of their immunosuppressive function can be induced by such factors as IL-1 $\beta$, IFN $\gamma, \mathrm{PGE}_{2}$, or Toll-like receptor ligands [8]. While the above MDSC-activating factors have apparently diverse character and functions, they all share the ability to induce COX2 expression and $\mathrm{PGE}_{2}$ production [52-54], suggesting the key role of $\mathrm{COX} 2$ and $\mathrm{PGE}_{2}$ in MDSCs development.

Peripheral blood-derived monocytes provide a convenient source of cells for cellular therapy due to their relative abundance in the circulation. We used peripheral blood PBMCs, obtained from the blood of healthy donors (Central Blood Bank of Pittsburgh, PA) using lymphocyte separation medium, to isolate monocytes by positive magnetic selection using the $\mathrm{CD} 14^{+}$isolation kit (EasySep 

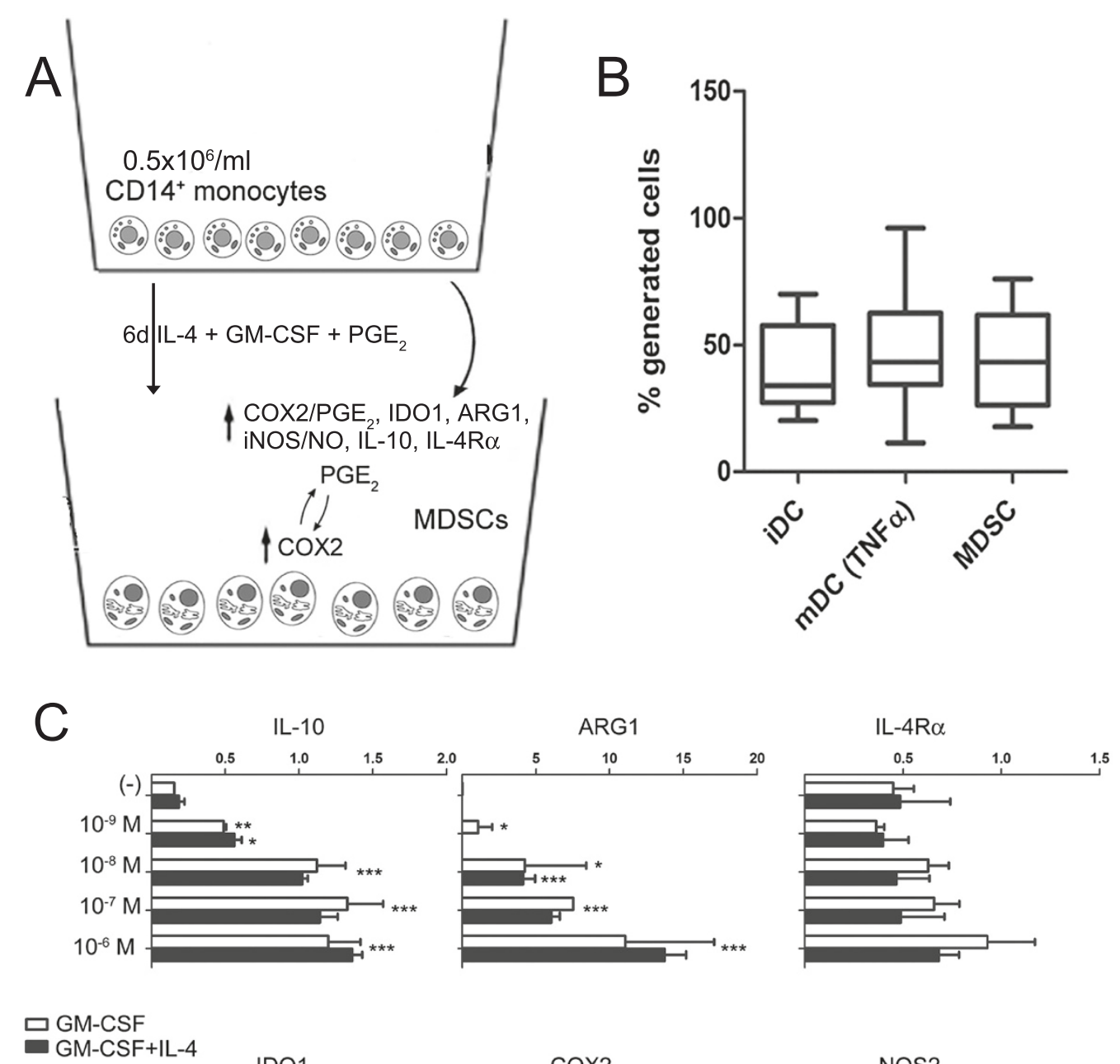

IDO1

$\operatorname{cox} 2$

NOS2
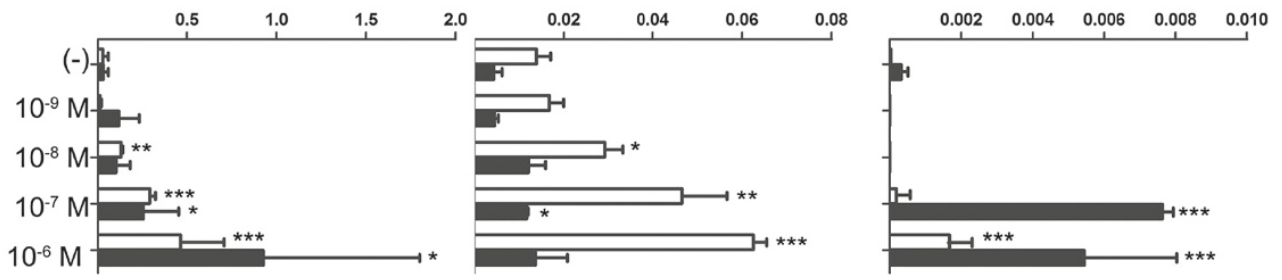

Figure 1 Prostaglandin $E_{2}$-induced positive cyclooxygenase 2-prostaglandin $E_{2}$-E-prostanoid receptor 2/4 feedback loop allows for ex vivo generation of high numbers of myeloid-derived suppressor cells and their functional stability. (A) Prostaglandin $E_{2}\left(P G E_{2}\right)$ (via E-prostanoid receptor (EP)2- and EP4-dependent signals) drives the early induction of cyclooxygenase (COX)2 in local myeloid cells (monocytes, macrophages, immature dendritic cells (iDCs)), promoting their production of suppressive factors (indoleamine 2,3-dioxygenase (IDO) 1, IL-10, arginase 1, nitric oxide synthase (NOS)2, and PGE 2 itself (current data and [48]), and acquisition of suppressive functions [48]. These processes are further amplified by the de novo production of endogenous $\mathrm{PGE}_{2}$, now produced at high levels by myeloid-derived suppressor cells (MDSCS) themselves, thereby creating a positive feedback loop leading to persistence of MDSCs. The key role of the EP2- and EP4-mediated COX2-PGE 2 feedback to control multiple aspects of MDSCs function provides convenient targets to generate MDSC-associated immune regulation in tolerogenic therapies. (B) PGE 2 induces high numbers of MDSCs (48.6\%), with yields similar to iDCs (40.2\%) and TNF-a matured DCs (36.9\%). Percentages indicate the yields of the cells generated in day 6 monocyte cultures performed in the presence of granulocyte macrophage colony stimulating factor (GM-CSF) and IL-4 in the absence of PGE $\left(i D C, C D 1 a^{+}\right.$DCSIGN $\left.^{+} \mathrm{CD}_{14}^{-} \mathrm{CD} 80^{-} \mathrm{CD} 83^{-}\right)$or presence of PGE 2 (MDSCs, CD1a

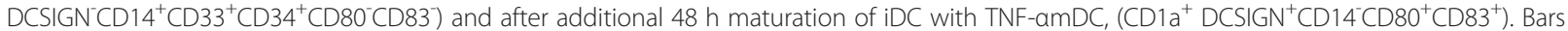
present data (mean \pm s.d.) from 12 different experiments with different donors. (C) Dose-dependent induction of immunosuppressive factors IL10, IDO1, IL4Ra and COX2 in PGE 2 -induced MDSCs, generated in the presence or absence of IL-4 (relative mRNA levels normalized for hypoxanthine phosphoribosyltransferase 1 and expressed as fold increase $\left(2^{-\Delta C T}\right.$ ), where $\Delta C T=C T$ (Target gene) $-C T$ (HPRT1). Bars present data (mean \pm s.d) of a single representative experiment with different donors. ${ }^{*} P<0.05,{ }^{* *} P<0.01,{ }^{* * *} P<0.001$, statistically significant differences relative to medium alone. 
Isolation kit; Stem Cell Tech, Vancouver, Canada). Monocytes were cultured for 6 days in 12 or 24-well plates at $5 \times 10^{5}$ cells per well in rhuGM-CSF and IL-4 (both 1000 $\mathrm{U} / \mathrm{ml}$; gifts from Schering Plough, Kenilworth, NJ), with $10^{-6} \mathrm{M} \mathrm{PGE}_{2}\left(\mathrm{PGE}_{2}\right.$-induced MDSCs, Sigma, St Louis, MO, USA) (Figure 1A). Alternatively, the E-prostanoid receptor (EP)2 agonist Butaprost (10 $\mu \mathrm{M}$, Sigma) and the EP4 agonist CAY10598 (10 nM, Cayman Chemical, Ann Arbor, MI, USA) were used to generate MDSCs. EP2 and EP4 are the two subtypes of the G protein-coupled receptor, signaling of which is coupled to a rise in cAMP concentration [55]. As shown in Figure 1B, the yield of $\mathrm{PGE}_{2}$-induced MDSCs (CD1a DCSIGNCD14 ${ }^{+} \mathrm{CD} 33^{+}$ $\left.\mathrm{CD} 34^{+} \mathrm{CD}^{-} 0^{-} \mathrm{CD}^{-} 3^{-}\right)$was similar to the yield of iDCs $\left(\mathrm{CD}_{1 \mathrm{a}^{+} \mathrm{DCSIGN}}{ }^{+} \mathrm{CD} 14^{-} \mathrm{CD} 80^{-} \mathrm{CD} 83^{-}\right)$and TNF- $\alpha$-matured (rhuTNFo, $50 \mathrm{ng} / \mathrm{ml}$, Strathmann Biotech, Germany) DCs $\left(\mathrm{CD}^{+}{ }^{+} \mathrm{DCSIGN}^{+} \mathrm{CD} 14{ }^{-} \mathrm{CD} 80^{+} \mathrm{CD} 83^{+}\right)$.

The differentiation of monocytes into functional $\mathrm{CD} \mathrm{a}^{+}$ DCs could be redirected into $\mathrm{CD} 1 \mathrm{a}^{-} \mathrm{CD} 14^{+} \mathrm{CD} 80^{-} \mathrm{CD} 83^{-}$ MDSCs by their exposure to $\mathrm{PGE}_{2}$ only at early stages of DC development (that is, from day 0, $\mathrm{PGE}_{2}^{\mathrm{d} 0}$ [ [29] but not at later time points (that is, at day $6, \mathrm{PGE}_{2}$-conditioned $\mathrm{DCs}^{\mathrm{d}}{ }^{\mathrm{d}}$ ).

While the immunosuppressive phenotype of the $\mathrm{PGE}_{2}-$ induced MDSCs proved to be $\mathrm{PGE}_{2}$ concentrationdependent (Figure 1C) [29], it was independent of the presence of IL-4, indicating a key role for $\mathrm{PGE}_{2}$, but not for IL-4, in inducing MDSCs.

Exposure to $\mathrm{PGE}_{2}$ induced the expression of endogenous COX2 in differentiating monocytes, leading to the establishment of a $\mathrm{PGE}_{2}-\mathrm{COX} 2$-mediated positive feedback loop, and the induction of IDO1, NOS2, IL-10, or IL-4R - the typical MDSC-associated factors (Figure 1C). $\mathrm{PGE}_{2}$-induced cells displayed a suppressive phenotype, marked by the expression of inhibitory molecules - inhibitory receptor Ig-like transcript (ILT)2, ILT3, ILT4 and programmed cell death 1 ligand 1 (previously implicated in the suppressive functions of myeloid cells $[27,28]$ ), produced the immunosuppressive factors IDO1, IL10 and $\mathrm{PGE}_{2}$ and exerted suppressive functions, blocking the proliferation and development of $\mathrm{CD}^{+} \mathrm{T}$ cells into granzyme $\mathrm{B}(\mathrm{GrB})^{\text {high }}$ cytotoxic T lymphocytes [33].

Additionally, $\mathrm{PGE}_{2}$ induced a uniform expression of high levels of CXCR4 [34], typically present on MDSCs from cancer-bearing individuals [56], and strong migratory responsiveness to CXCL12 [34].

\section{Therapeutic potential of ex vivo induced myeloid- derived suppressor cells}

Anti-inflammatory activity of MDSCs in a variety of physiological settings and their therapeutic promise in transplantation [57] suggest that these cells may provide a novel cell-based immunotherapy in transplantation $[40,58]$ and autoimmune diseases [59].

While the spontaneously arising endogenous MDSCs present in many forms of autoimmune diseases appear to be defective and ineffective in controlling the disease (reviewed in [60]), it was shown that adoptive transfer of MDSCs can limit autoimmune pathology [61-63], providing a rationale for the development of methods to expand or induce MDSCs ex vivo.

Transfer of MDSCs can prevent graft-versus-host disease [42], and prolong the survival of allo-skin [64] and allo-kidney transplants [65], and play an essential role in an allogeneic cardiac transplantation model [57]. Adoptively transferred MDSCs, isolated from synegeic tumorbearing mice, can prevent the onset of type 1 diabetes in non-obese diabetic mice [63] and ameliorate the symptoms of inflammatory bowel disease [59]. In a mouse model of alopecia, adoptively transferred MDSCs have been shown to promote partial restoration of hair growth [62].

From the therapeutic standpoint, it is important to identify central regulatory pathways that maintain the suppressive functions of MDSCs mediated by different suppressive molecules (arginase 1 [42], ILT-2 [66], heme-oxygenase (HO-1) [64], and iNOS [65]). Our data [48,67] - showing that the exposure of differentiating monocytes to $\mathrm{PGE}_{2}$ (and the establishment of a positive feedback between $\mathrm{PGE}_{2}$ and COX2) is both required and sufficient for MDSC stability and their ability to produce all MDSC-associated suppressive mediators and suppress $\mathrm{CD}^{+} \mathrm{T}$ cell function [48] provides evidence for a feasible and clinically compatible method of generating suppressive cells for immunotherapeutic purposes.

\section{Conclusions}

Due to their ability to suppress $\mathrm{T}$ cell responses in multiple diseases $[65,68,69]$, MDSCs represent a promising population of cells for use in tolerogenic therapies. Our recent observations demonstrating the feasibility of using $\mathrm{PGE}_{2}$ to promote the development of MDSCs from monocytic precursors provide a clinically feasible system of generating large numbers of MDSCs ex vivo, facilitating the development of new therapies for autoimmune diseases and transplant rejection.

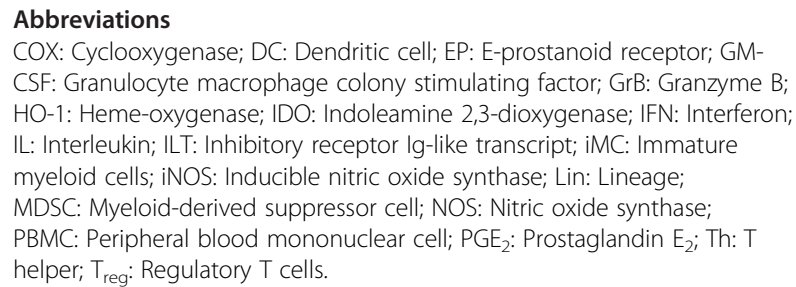

Competing interests

The authors declare that they have no competing interests.

\section{Authors' contributions}

$\mathrm{NO}$ and PK conceived the work and wrote the manuscript. Both authors read and approved the final manuscript. 


\section{Acknowledgements}

This work was supported by grants from the NIH (1P01 CA132714; 5T32 CA082084) and by a UICC American Cancer Society Beginning Investigators Fellowship funded by the American Cancer Society.

\section{Author details}

${ }^{1}$ Departments of Surgery, University of Pittsburgh, Hillman Cancer Center, Pittsburgh, PA 15213, USA. ²Departments of Immunology, University of Pittsburgh, Hillman Cancer Center, Pittsburgh, PA 15213, USA. ${ }^{3}$ Infectious Diseases and Microbiology, University of Pittsburgh, Pittsburgh, PA 15213, USA. ${ }^{4}$ University of Pittsburgh Cancer Institute, University of Pittsburgh, Hillman Cancer Center, Pittsburgh, PA 15213, USA. ${ }^{5}$ Department of Surgery, University of Pittsburgh, Hillman Cancer Center, UPCI Research Pavilion, Room 1.46, 5117 Center Avenue, Pittsburgh, PA 15213-1863, USA.

Received: 23 May 2012 Accepted: 2 July 2012

Published: 28 September 2012

\section{References}

1. Pulendran B, Palucka K, Banchereau J: Sensing pathogens and tuning immune responses. Science 2001, 293:253-256.

2. Palucka K, Ueno H, Roberts L, Fay J, Banchereau J: Dendritic cells: are they clinically relevant? Cancer J 2010, 16:318-324.

3. Torres-Aguilar H, Blank M, Jara $L$, Shoenfeld $Y$ : Tolerogenic dendritic cells in autoimmune diseases: crucial players in induction and prevention of autoimmunity. Autoimmun Rev 2010, 10:8-17.

4. Pulendran $B$, Tang H, Manicassamy S: Programming dendritic cells to induce $\mathrm{T}(\mathrm{H}) 2$ and tolerogenic responses. Nat Immuno 2010, 11:647-655.

5. Macedo C, Turquist $H$, Metes D, Thomson AW: Immunoregulatory properties of rapamycin-conditioned monocyte-derived dendritic cells and their role in transplantation. Transplantation Res 2012, 1:16.

6. Amodo G, Gregori S: Human tolerogenic DC-10: perspectives for clinical Applications. Transplantation Res 2012, 1:14

7. Riquelme P, Geissler EK, Hutchinson JA: Alternative approaches to myeloid suppressor cell therapy in transplantation: comparing regulatory macrophages to tolerogenic DCs and MDSCs. Transplantation Res 2012, $1: 17$.

8. Condamine T, Gabrilovich DI: Molecular mechanisms regulating myeloidderived suppressor cell differentiation and function. Trends Immunol 2011, 32:19-25.

9. Gabrilovich D: Mechanisms and functional significance of tumourinduced dendritic-cell defects. Nat Rev Immunol 2004, 4:941-952.

10. Gabrilovich DI, Nagaraj S: Myeloid-derived suppressor cells as regulators of the immune system. Nat Rev Immunol 2009, 9:162-174.

11. Rabinovich GA, Gabrilovich D, Sotomayor EM: Immunosuppressive strategies that are mediated by tumor cells. Annu Rev Immunol 2007, 25:267-296

12. Sinha P, Clements VK, Bunt SK, Albelda SM, Ostrand-Rosenberg S: Cross-talk between myeloid-derived suppressor cells and macrophages subverts tumor immunity toward a type 2 response. J Immunol 2007, 179:977-983.

13. Filipazzi P, Valenti R, Huber V, Pilla L, Canese P, lero M, Castelli C, Mariani L, Parmiani G, Rivoltini L: Identification of a new subset of myeloid suppressor cells in peripheral blood of melanoma patients with modulation by a granulocyte-macrophage colony-stimulation factorbased antitumor vaccine. J Clin Oncol 2007, 25:2546-2553.

14. Vuk-Pavlovic S, Bulur PA, Lin Y, Qin R, Szumlanski CL, Zhao X, Dietz AB: Immunosuppressive CD14 + HLA-DRlow/- monocytes in prostate cancer. Prostate 2010, 70:443-455.

15. Mundy-Bosse BL, Young GS, Bauer T, Binkley E, Bloomston M, Bill MA, BekaiiSaab T, Carson WE 3rd, Lesinski GB: Distinct myeloid suppressor cell subsets correlate with plasma IL- 6 and IL-10 and reduced interferonalpha signaling in CD4(+) T cells from patients with GI malignancy. Cancer Immunol Immunother 2011, 60:1269-1279.

16. Hoechst B, Voigtlaender T, Ormandy L, Gamrekelashvili J, Zhao F, Wedemeyer H, Lehner F, Manns MP, Greten TF, Korangy F: Myeloid derived suppressor cells inhibit natural killer cells in patients with hepatocellular carcinoma via the NKp30 receptor. Hepatology 2009, 50:799-807.

17. Hoechst B, Ormandy LA, Ballmaier M, Lehner F, Kruger C, Manns MP, Greten TF, Korangy F: A new population of myeloid-derived suppressor cells in hepatocellular carcinoma patients induces CD4(+)CD25(+)Foxp3(+) T cells. Gastroenterology 2008, 135:234-243.
18. Raychaudhuri B, Rayman P, Ireland J, Ko J, Rini B, Borden EC, Garcia J, Vogelbaum MA, Finke J: Myeloid-derived suppressor cell accumulation and function in patients with newly diagnosed glioblastoma. Neuro Oncol 2011, 13:591-599.

19. Mellor AL, Munn DH: IDO expression by dendritic cells: tolerance and tryptophan catabolism. Nat Rev Immunol 2004, 4:762-774.

20. Hwu P, Du MX, Lapointe R, Do M, Taylor MW, Young HA: Indoleamine 2,3dioxygenase production by human dendritic cells results in the inhibition of T cell proliferation. J Immunol 2000, 164:3596-3599.

21. Ochoa AC, Zea AH, Hernandez C, Rodriguez PC: Arginase, prostaglandins, and myeloid-derived suppressor cells in renal cell carcinoma. Clin Cancer Res 2007, 13:721s-726s.

22. Bronte $\mathrm{V}$, Zanovello P: Regulation of immune responses by L-arginine metabolism. Nat Rev Immunol 2005, 5:641-654.

23. Corzo CA, Cotter MJ, Cheng P, Cheng F, Kusmartsev S, Sotomayor E, Padhya T, McCaffrey TV, McCaffrey JC, Gabrilovich DI: Mechanism regulating reactive oxygen species in tumor-induced myeloid-derived suppressor cells. J Immunol 2009, 182:5693-5701

24. Bronte V, Serafini P, Apolloni E, Zanovello P: Tumor-induced immune dysfunctions caused by myeloid suppressor cells. J Immunother 2001, 24:431-446.

25. Kusmartsev S, Nagaraj S, Gabrilovich Dl: Tumor-associated CD8+ T cell tolerance induced by bone marrow-derived immature myeloid cells. $J$ Immunol 2005, 175:4583-4592.

26. Li H, Han Y, Guo Q, Zhang M, Cao X: Cancer-expanded myeloid-derived suppressor cells induce anergy of NK cells through membrane-bound TGF-beta 1. J Immunol 2009, 182:240-249.

27. Liu Y, Zeng B, Zhang Z, Zhang Y, Yang R: B7-H1 on myeloid-derived suppressor cells in immune suppression by a mouse model of ovarian cancer. Clin Immunol 2008, 129:471-481.

28. Curiel TJ, Wei S, Dong H, Alvarez X, Cheng P, Mottram P, Krzysiek R, Knutson KL, Daniel B, Zimmermann MC, David O, Burow M, Gordon A, Dhurandhar $\mathrm{N}$, Myers L, Berggren R, Hemminki A, Alvarez RD, Emilie D, Curiel DT, Chen L, Zou W: Blockade of B7-H1 improves myeloid dendritic cell-mediated antitumor immunity. Nat Med 2003, 9:562-567.

29. Kalinski P, Hilkens CM, Snijders A, Snijdewint FG, Kapsenberg ML: IL-12 deficient dendritic cells, generated in the presence of prostaglandin E2, promote type 2 cytokine production in maturing human naive T helper cells. J Immunol 1997, 159:28-35.

30. Huang M, Stolina M, Sharma S, Mao JT, Zhu L, Miller PW, Wollman J, Herschman H, Dubinett SM: Non-small cell lung cancer cyclooxygenase-2dependent regulation of cytokine balance in lymphocytes and macrophages: up-regulation of interleukin 10 and down-regulation of interleukin 12 production. Cancer Res 1998, 58:1208-1216.

31. Stolina M, Sharma S, Lin Y, Dohadwala M, Gardner B, Luo J, Zhu L, Kronenberg M, Miller PW, Portanova J, Lee JC, Dubinett SM: Specific inhibition of cyclooxygenase 2 restores antitumor reactivity by altering the balance of IL-10 and IL-12 synthesis. J Immunol 2000, 164:361-370.

32. Heusinkveld M, de Vos van Steenwijk PJ, Goedemans R, Ramwadhdoebe TH Gorter A, Welters MJ, van Hall T, van der Burg SH: M2 macrophages induced by prostaglandin E2 and IL- 6 from cervical carcinoma are switched to activated M1 macrophages by CD4+ Th1 cells. J Immunol 2011, 187:1157-1165.

33. Obermajer N, Muthuswamy R, Lesnock J, Edwards RP, Kalinski P: Positive feedback between PGE2 and COX2 redirects the differentiation of human dendritic cells toward stable myeloid-derived suppressor cells. Blood 2011, 118:5498-5505.

34. Obermajer N, Muthuswamy R, Odunsi K, Edwards RP, Kalinski P: PGE2 induced CXCL12 production and CXCR4 expression controls the accumulation of human MDSCs in ovarian cancer environment. Cancer Res 2011, 71:7463-7470.

35. Kalinski P: Regulation of immune responses by prostaglandin E2. Immunol 2012, 188:21-28.

36. Sinha P, Clements VK, Fulton AM, Ostrand-Rosenberg S: Prostaglandin E2 promotes tumor progression by inducing myeloid-derived suppressor cells. Cancer Res 2007, 67:4507-4513.

37. Rodriguez PC, Hernandez CP, Quiceno D, Dubinett SM, Zabaleta J, Ochoa JB, Gilbert J, Ochoa AC: Arginase I in myeloid suppressor cells is induced by COX-2 in lung carcinoma. J Exp Med 2005, 202:931-939.

38. Eruslanov E, Daurkin I, Ortiz J, Vieweg J, Kusmartsev S: Pivotal advance: tumor-mediated induction of myeloid-derived suppressor cells and M2- 
polarized macrophages by altering intracellular PGE2 catabolism in myeloid cells. J Leukoc Biol 2010, 88:839-848.

39. Zhou Z, French DL, Ma G, Eisenstein S, Chen Y, Divino CM, Keller G, Chen SH, Pan PY: Development and function of myeloid-derived suppressor cells generated from mouse embryonic and hematopoietic stem cells. Stem Cells 2010, 28:620-632.

40. Boros P, Ochando JC, Chen SH, Bromberg JS: Myeloid-derived suppressor cells: natural regulators for transplant tolerance. Hum Immunol 2010, 71:1061-1066.

41. MacDonald KP, Rowe V, Clouston AD, Welply JK, Kuns RD, Ferrara JL, Thomas R, Hill GR: Cytokine expanded myeloid precursors function as regulatory antigen-presenting cells and promote tolerance through IL10-producing regulatory T cells. J Immunol 2005, 174:1841-1850.

42. Highfill SL, Rodriguez PC, Zhou Q, Goetz CA, Koehn BH, Veenstra R, Taylor PA, Panoskaltsis-Mortari A, Serody JS, Munn DH, Tolar J, Ochoa AC, Blazar BR: Bone marrow myeloid-derived suppressor cells (MDSCs) inhibit graftversus-host disease (GVHD) via an arginase-1-dependent mechanism that is up-regulated by interleukin-13. Blood 2010, 116:5738-5747.

43. Marigo I, Bosio E, Solito S, Mesa C, Fernandez A, Dolcetti L, Ugel S, Sonda N, Bicciato S, Falisi E, Calabrese F, Basso G, Zanovello P, Cozzi E, Mandruzzato S, Bronte V: Tumor-induced tolerance and immune suppression depend on the C/EBPbeta transcription factor. Immunity 2010, 32:790-802.

44. Arora M, Poe SL, Oriss TB, Krishnamoorthy N, Yarlagadda M, Wenzel SE, Billiar TR, Ray A, Ray P: TLR4/MyD88-induced CD11b + Gr-1 int F4/80+ non-migratory myeloid cells suppress Th2 effector function in the lung. Mucosal Immunol 2010, 3:578-593.

45. Dolcetti L, Peranzoni E, Ugel S, Marigo I, Fernandez Gomez A, Mesa C, Geilich M, Winkels G, Traggiai E, Casati A, Grassi F, Bronte V: Hierarchy of immunosuppressive strength among myeloid-derived suppressor cell subsets is determined by GM-CSF. Eur I Immunol 2010, 40:22-35.

46. Valenti R, Huber V, Filipazzi P, Pilla L, Sovena G, Villa A, Corbelli A, Fais S, Parmiani G, Rivoltini L: Human tumor-released microvesicles promote the differentiation of myeloid cells with transforming growth factor-betamediated suppressive activity on T lymphocytes. Cancer Res 2006, 66:9290-9298.

47. Lechner MG, Liebertz DJ, Epstein AL: Characterization of cytokine-induced myeloid-derived suppressor cells from normal human peripheral blood mononuclear cells. J Immunol 2010, 185:2273-2284.

48. Obermajer N, Muthuswamy R, Lesnock J, Edwards RP, Kalinski P: Positive feedback between PGE2 and COX2 redirects the differentiation of human dendritic cells toward stable myeloid-derived suppressor cells. Blood 2011, 118:5498-5505.

49. Chomarat P, Banchereau J, Davoust J, Palucka AK: IL-6 switches the differentiation of monocytes from dendritic cells to macrophages. Nat Immunol 2000, 1:510-514.

50. Gabrilovich D, Ishida T, Oyama T, Ran S, Kravtsov V, Nadaf S, Carbone DP: Vascular endothelial growth factor inhibits the development of dendritic cells and dramatically affects the differentiation of multiple hematopoietic lineages in vivo. Blood 1998, 92:4150-4166.

51. Menetrier-Caux C, Montmain G, Dieu MC, Bain C, Favrot MC, Caux C, Blay JY: Inhibition of the differentiation of dendritic cells from CD34(+) progenitors by tumor cells: role of interleukin- 6 and macrophage colony-stimulating factor. Blood 1998, 92:4778-4791.

52. Eliopoulos AG, Dumitru CD, Wang CC, Cho J, Tsichlis PN: Induction of COX2 by LPS in macrophages is regulated by Tpl2-dependent CREB activation signals. EMBO J 2002, 21:4831-4840.

53. Faour WH, He Y, He QW, de Ladurantaye M, Quintero M, Mancini A, D Battista JA: Prostaglandin E(2) regulates the level and stability of cyclooxygenase-2 mRNA through activation of p38 mitogen-activated protein kinase in interleukin-1 beta-treated human synovial fibroblasts. $J$ Biol Chem 2001, 276:31720-31731.

54. Blanco JC, Contursi C, Salkowski CA, DeWitt DL, Ozato K, Vogel SN: Interferon regulatory factor (IRF)-1 and IRF-2 regulate interferon gammadependent cyclooxygenase 2 expression. J Exp Med 2000, 191:2131-2144.

55. Sugimoto Y, Narumiya S: Prostaglandin E receptors. J Biol Chem 2007, 282:11613-11617.

56. Eruslanov E, Neuberger M, Daurkin I, Perrin GQ, Algood C, Dahm P, Rosser C, Vieweg J, Gilbert SM, Kusmartsev S: Circulating and tumor-infiltrating myeloid cell subsets in patients with bladder cancer. Int J Cancer 2011, 130:1109-1119.
57. Garcia MR, Ledgerwood L, Yang Y, XU J, Lal G, Burrell B, Ma G, Hashimoto D, Li Y, Boros P, Grisotto M, van Rooijen N, Matesanz R, Tacke F, Ginhoux F, Ding Y, Chen SH, Randolph G, Merad M, Bromberg JS, Ochando JC: Monocytic suppressive cells mediate cardiovascular transplantation tolerance in mice. J Clin Invest 2010, 120:2486-2496.

58. Lees JR, Azimzadeh AM, Bromberg JS: Myeloid derived suppressor cells in transplantation. Curr Opin Immunol 2011, 23:692-697.

59. Haile LA, von Wasielewski R, Gamrekelashvili J, Kruger C, Bachmann O, Westendorf AM, Buer J, Liblau R, Manns MP, Korangy F, Greten TF: Myeloidderived suppressor cells in inflammatory bowel disease: a new immunoregulatory pathway. Gastroenterology 2008, 135:871-881.

60. Cripps JG, Gorham JD: MDSC in autoimmunity. Int Immunopharmacol 2011 , 11:789-793.

61. Westendorf AM, Fleissner D, Deppenmeier S, Gruber AD, Bruder D, Hansen W, Liblau R, Buer J: Autoimmune-mediated intestinal inflammationimpact and regulation of antigen-specific CD8+ T cells. Gastroenterology 2006, 131:510-524.

62. Marhaba R, Vitacolonna M, Hildebrand D, Baniyash M, Freyschmidt-Paul P, Zoller M: The importance of myeloid-derived suppressor cells in the regulation of autoimmune effector cells by a chronic contact eczema. $J$ Immunol 2007, 179:5071-5081.

63. Yin B, Ma G, Yen CY, Zhou Z, Wang GX, Divino CM, Casares S, Chen SH, Yang WC, Pan PY: Myeloid-derived suppressor cells prevent type 1 diabetes in murine models. J Immunol 2010, 185:5828-5834.

64. De Wilde V, Van Rompaey N, Hill M, Lebrun JF, Lemaître P, Lhommé F, Kubjak C, Vokaer B, Oldenhove G, Charbonnier LM, Cuturi MC, Goldman M, Le Moine A: Endotoxin-induced myeloid-derived suppressor cells inhibit alloimmune responses via heme oxygenase-1. Am J Transplant 2009, 9:2034-2047.

65. Dugast AS, Haudebourg T, Coulon F, Heslan M, Haspot F, Poirier N, de Vuillefroy SR, Usal C, Smit H, Martinet B, Thebault P, Renaudin K, Vanhove B: Myeloid-derived suppressor cells accumulate in kidney allograft tolerance and specifically suppress effector T cell expansion. J Immunol 2008, 180:7898-7906.

66. Zhang W, Liang S, Wu J, Horuzsko A: Human inhibitory receptor immunoglobulin-like transcript 2 amplifies CD11b + Gr1+ myeloidderived suppressor cells that promote long-term survival of allografts. Transplantation 2008, 86:1125-1134.

67. Serafini P: Editorial: PGE2-producing MDSC: a role in tumor progression? J Leukoc Biol 2010, 88:827-829.

68. Delano MJ, Scumpia PO, Weinstein JS, Coco D, Nagaraj S, Kelly-Scumpia KM, O'Malley KA, Wynn JL, Antonenko S, Al-Quran SZ, Swan R, Chung CS, Atkinson MA, Ramphal R, Gabrilovich DI, Reeves WH, Ayala A, Phillips J, Laface D, Heyworth PG, Clare-Salzler M, Moldawer LL: MyD88-dependent expansion of an immature GR-1(+)CD11b(+) population induces T cell suppression and Th2 polarization in sepsis. J Exp Med 2007, 204:1463-1474.

69. Zhu B, Bando Y, Xiao S, Yang K, Anderson AC, Kuchroo VK, Khoury SJ: CD11b + Ly-6C(hi) suppressive monocytes in experimental autoimmune encephalomyelitis. J Immunol 2007, 179:5228-5237.

doi:10.1186/2047-1440-1-15

Cite this article as: Obermajer and Kalinski: Generation of myeloid-

derived suppressor cells using prostaglandin $\mathrm{E}_{2}$. Transplantation Research 2012 1:15.

\section{Submit your next manuscript to BioMed Central and take full advantage of:}

- Convenient online submission

- Thorough peer review

- No space constraints or color figure charges

- Immediate publication on acceptance

- Inclusion in PubMed, CAS, Scopus and Google Scholar

- Research which is freely available for redistribution 